\title{
Value Creation Model through Corporate Social Responsibility (CSR)
}

\author{
Saeed Gholami \\ Doctor of Business Administration (DBA) \\ MMU University- Kuala Lumpur, Malaysia \\ Tel: 60-13-698-7606 E-mail: gholami.mmu@gmail.com
}

Received: January 6, 2011 Accepted: February 9, $2011 \quad$ doi:10.5539/ijbm.v6n9p148

\begin{abstract}
Corporate social responsibility (CSR) is a modern mechanism of accountability in the business world and competitive era. The notion of CSR is established on the reciprocal dependence between a organization and society, as well as the indicators that influence this relationship. Therefore, corporate social responsibility via design the elements of organization such as strategy, resource and process, business propositions, and stakeholder interactions create value for corporations and society and also can represent an excellence image in both internal and external environment through enhancing accountability for society.
\end{abstract}

Keywords: Corporate social responsibility (CSR), Value creation (VC), Organizational performance (OP)

\section{Introduction / Background}

Different pressures such as political, legal, economic, and environment and various benchmarking in the local, national. And international cause enhances competition intensity. These parameters, in turn, create a crucial atmosphere and conditions in the modern commercial era. Therefore, companies and their managers must play an active role in the welfare of society so that gain an acceptable image in order to achieve high performance. As well as these conditions not only implement by public sector but application also by private sector.

Today's corporate social responsibility (CSR) has become a new tool for organizations and their managers in the modern commercial era. The concept of CSR is based on the mutual dependence between a corporate and society as well as the indicators that affect this relationship. There are some interactions plays in this relationship: corporate and stakeholders, corporate and governments, corporate and environment, corporate and ethical, and corporate and sustainable competitive advantage (Bowen 1953; Stanwick and Stanwick 1998; Maignan and Ralston 2002; Aguilera, Rupp et al. 2004).

The SCR consisting of four kinds of responsibilities: economic, legal, ethical, and philanthropy (Carroll 1999). Full disclosure, equal positions for employees, philanthropy, environmental actions, and quality of products and services are variables to measure four types of SCR (Maignan, Ferrell et al. 1999; Aras, Aybars et al. 2010).

Four kinds of responsibilities through SCR's aspects create value for both internal (organization or corporate) environment and external environment including society or country. Corporate social responsibility is a broader mechanism and new approach for enhancing accountability about society and country by top management. As well as help corporate and their managers so that use from various opportunities and reducing costs. Therefore, CSR is a modern approach whereby organizations shift excellence corporate citizenship (Normann and Ramirez 1993).

Organizational performance divide into two subcategories including financial performance variables such as stock price change, price per share change, ROI, ROE, and ROA (Hackston and Milne 1996). Non-financial variables including reputation, attract more talented, committed employees, customer satisfaction, capital market response, shareholder quietly, joint venture, and new acquisitions (Maignan, Ferrell et al. 1999; McWilliams, Siegel et al. 2006).Using from some of organization dimensions such as size, culture, environment, and technology as control variables can be effected in this project (Daft and Lewin 1993).

Therefore, the CSR is important and elemental to the sustainable operations of companies; on the other hand organizational performance $(\mathrm{OP})$ is doubtless basically to the ongoing operation for any company. This paper aims to investigate the claims that CSR and OP are linked and can test or measure it.

A key message of this study present a new framework to mangers is that how SCR cause improvement OP. consequently mangers learn that use from SCR as new tool to improve excellent image in the their organizations and society. As well as design new opportunities to enhance their corporate to create value for stakeholders and transfer threats to opportunities according to obtained positive image and reputation. 


\section{Research objectives}

The general objective of this paper is using literature review about corporate social responsibility that produces value creation for organizations and society. The specific objectives are to:

1- To design holistic framework in the corporate social responsibility according literature review.

2- To consider the role of CSR in create value within organization and society.

3- To study linkage between CSR and organizational performance.

4- To determine dependent, independent, and control variables.

\section{Literature review}

According to Bowen (1953), theoretical and empirical researches point to Haward Bowen's social responsibility of the businessman as primary study that consider and evaluate about relationship between corporations and society. Some of these researches include (Carroll 1979) and (Aupperle, Carroll et al. 1985). After these researches, most studies concentrate on the corporate social responsibility in the business and social environment as process and also focus on application it. For example, using from behavior analysis as a method for solution of social problem is one of them (Fitch 1976).

During 1981s to 1990s, some studies have been done regarding measurement of the relationship between corporate social responsibility and financial performance. In these studies have been confirmed the relationship between CSR and financial performance (Ullmann 1985; McGuire, Sundgren et al. 1988). Most important study on the 1991s is Carroll's pyramid of corporate social responsibility. This is most famous example about CSR. This model focuses on hierarchy of responsibilities and has four levels of responsibilities including economic, legal, ethical, and philanthropic levels (Carroll 1979).

This paper focuses on it as dimensions of corporate social responsibility for design new framework because these elements can create value in each level of responsibility for corporations and society. The Carroll's pyramid revised and 3C-SR model replaced it (Schwartz and Carroll 2003).

The 3C-SR model emphasize because of discretionary nature of the social responsibility, the philanthropic category as not justifiable. Later on the 3C-SR model modified and shifted toward contemporary impressions of corporate social responsibility as fundamental to the business system and represented in concepts. Some of the modern models are triple bottom line including people, planet, and profit and social auditing (Schwartz and Carroll 2003; Meehan, Meehan et al. 2006).

Corporate social responsibility as an extensive concept has various meaning. Among these terms, corporate social performance, corporate social responsiveness, stakeholder management, corporate citizenship, and corporate social responsibility are more common. There are a large number studies that confirmed them (Carroll 1979; Wood 1991; Turban and Daniel 1996; Stanwick and Stanwick 1998; Maignan, Ferrell et al. 1999; Shropshire and Hillman 2007).

The most important point in these researches is related to how corporate social responsibility is measured. The three methods are that contribute in the measuring CSR (McGuire, Sundgren et al. 1988). The first method is the knowledgeable or specialist evaluations about the policies of corporate. In this method is very important that access to all scope of the routine and non-routine activities within corporation and also the expertness of the researchers. As well as the accuracy of this method depends on these important factors (Abbott and Monsen 1979; Márquez and Fombrun 2005; Luo and Bhattacharya 2006).

The content investigation and examination of annual reports and documents of corporate is the second method. The content examination is defined a set of procedures and instructions to create valid deduction from text (Weber 1990; Basil and Weber 2006). And also content analysis is a technique research-based for creating replicable and valid deduction from texts to the contexts of their use. The important advantage of this method is when compared to the other methods (Krippendorff 2004).

The third method that use to measure corporate social responsibility is the performance of corporation in controlling pollution as a proxy measure. This method focuses on pollution that one of aspect or dimension of social responsibility. Therefore, this method is important for industries that pollution is meaningful issue. And also this factor can be a limitation in measurement process (Chen and Metcalf 1980; McGuire, Sundgren et al. 1988).

This paper points out some research that studied the relations of corporate social responsibility with other aspects such as financial performance, social and environmental performance, and so on. About one hundred twenty-seven published studies between 1970 and 2002 with different measurement methods have been done (Margolis and Walsh 2003). In these researches generally two main types of performance in the financial areas for investigation relationship between CSR and various aspects of corporation performance have been used.

One of the most related studies is financial performance measures based on accounting that is not suitable method, because has certain difficulties. For instance, it only exhibits historical company performance that creates through manipulation of the managers and generates results among companies due to the use from 
different accounting procedures which cannot be compared. The positive relationship between CSR and financial performance has been indicated by some of these researches (Margolis and Walsh 2003).

For example, the link between environmental management practices and financial performance (Montabon, Sroufe et al. 2007) and strong correlation between corporate financial and social and environmental performance (Orlitzky, Schmidt et al. 2003) are some of these studies. And also some researches investigate the linkage between company size and corporate social responsibility (Stanwick and Stanwick 1998; Udayasankar 2008).

These researches generate equivocal results and explore a u-formed linkage managing corporate performance between the contribution of corporate social responsibility and company size. According these studies, companies with very small and very large size being equally motivated to participated in corporate social responsibility with medium-sized companies being the least motivated (Udayasankar 2008). As a result, according to both modern stakeholder and agency theory, there is a positive relationship between corporate social responsibility and financial performance (Cochran and Wood 1984; McGuire, Sundgren et al. 1988; Waddock and Graves 1997; McWilliams and Siegel 2000).

This is very important for managers that how use from CSR in the modern business world. Because of the increasing of environmental awareness, increasing of shortage of resources, and the demand for transparency, managers should move toward using more and more from CSR so that create value for their organizations and society. The value creation must be as basic principle until top management design competitiveness strategies. Hence, this part of paper allocates value creation.

\section{Value creation}

Corporate social responsibility in a new approach helps company so that considers the interests of total stakeholders within both organization and society. And also company can use these interests developing its strategy and duration of implementation. Hence, there are some approaches that how CSR play as modern approach for value creation.

The first approach is community-based development (Maskrey 1989). This approach focuses on local communities that companies can better work with them. For example, establish Flower Valley in the South Africa by Shell Foundation is as sample of this approach that they establish an Early Learning Center to help to train the community's children and likewise as grow new skills for the adults. Other examples include building of the trade network, creation education facilities for HIV /AIDS education programs in the Africa and JIDF For You in Indian(Bansal and Roth 2000).

Integration the CSR strategy for contribution into the business strategy of a company is another approach (Baron 2001; Galbreath 2006). This approach creates a fair trade for players of the business field such as buyers and suppliers. For example, procure of Fair Trade tea and coffee has been selected through different business including KPMG (Bansal and Roth 2000; Dentchev 2004)

Another approach is creating share value (CSV) (Nohria and Ghoshal 1994). The basis of this approach is an idea that company success and social welfare are interdependent. According to this approach, some factors such as healthy, educated workforce, sustainable tangible and intangible resources and adept government are needed to compete effectively. As well as for society create income, wealth, tax revenues, and opportunities for the last level of Carroll's pyramid that it called philanthropy(Bansal and Roth 2000).

Some of approaches to corporate social responsibility emphasize the costs and restriction of compliance with externally imposed social and environment standards, but creation share value focuses on trade-off the objectives of social and environmental and short-term profitability. And likewise, emphasize the external environment for competitive advantage through threats and opportunities from making the proposition and hypothesis of social value into corporate strategy (Bansal and Roth 2000).

Earlier researches have used from value network that explains social and technical resources among businesses. Value network focuses on tangible and intangible resources for deliverable and interactions between them. Knowledge and other intangible and financial value are more effective in deliverables. As well as value networks show interdependence and account for the worth of products and services. Thus, corporations have two types of networks including internal and external (Normann and Ramirez 1993).

According to the Normann and Ramirez (1993) studies, value creation system there is in different economic players or actors. These actors are suppliers, partners of business, customers that work together to co-produce value for their organizations and society. As a result, strategy, resources and processes, business propositions, and stakeholders' interactions are main elements value network or cycle that many of them do not mentioned in the past researches. Hence, this paper considers them.

\section{Gaps in literature}

According to literature review, this paper investigates some gaps that are related to the project's title. They are:

1) In spite of the existing of strong literature about the role of corporate social responsibility in the aspects of environment and society, there is a significance gap about how corporate social responsibility can create value for corporations and society. 
2) Some studies pay attention linkage between corporate social responsibility and corporation and company size. However, many of dimensions of organization such as centralization and decentralization, formalization, particular culture, technology, and training have not been considered.

3) In spite of Carroll's pyramid and 3C-SR model, the lack of holistic framework that exhibit the process of value creation for organizations and society.

4) There is not any evidence about the relationship between corporate social responsibility and organization performance that include financial and non-financial performance.

According to explored gaps, this paper propose new framework to study and consider the linkage between CSR and organization performance.

\section{Propose new model}

New framework is composed of two main part including value creation cycle and organization performance. The first part designs according to the Carroll's pyramid and the second part is organization performance. As mentioned in the literature of the paper, the fundamental role of corporate social responsibility creates value for organizations and society. Both internal and external environment are effected in the value creation cycle. In continues, the paper explain each of them (figure 1).

In the new framework value creation cycle is consisted of four types of CSR's dimensions including economic, legal, ethical, and philanthropic dimensions. The economic dimensions focus on obligations for businesses to create wealth and to face consumption requirements. This dimension is important, because is the foundation upon for other dimensions, create maximizing earning per share, assert the position of strong competitive, and hold a high level of operational effectiveness. The new framework suggests personal saving rate, business saving rate, inflation rate, and manufacturing lead time indicators to measure the economic dimension.

The legal responsibilities dimension emphasize which the process of business should execute the vision and mission of their economic according to legal requirements. These responsibilities are important, because to carry out in a style uniform of government and law's expectation. And also is important for law-abiding company citizen. Therefore, corporate must produce goods and services that have minimum legal requirements. The paper proposes anti-trust laws, labor training laws, taxation laws and human right for measuring these responsibilities.

The third dimension of value creation cycle in the new framework is ethical responsibilities. This dimension focus on businesses abides that to do what is right, just and fair. Moral rules should define as suitable behaviors in the organizations and society. These responsibilities are important due to the expectations of social mores and ethical norms and recognition ethical or moral norms accepted by society. Some variables such as codes of conduct, corruption, and money laundering have suggested by this paper.

The philanthropic responsibilities are the last dimension of value creation cycle. These responsibilities that are called discretionary responsibilities emphasize be a good corporate citizen. And likewise focus on contribution resources for community and improve quality of life as a basic indicator for community. Because of some reasons such as charitable expectation of society, participation managers and employees in voluntary and charitable activities in local society, and establishing educational institutions are important. The new framework use from donor attrition, donor acquisition, gift processing time and stewardship calls as key variables estimation philanthropic responsibilities within society.

In the second part, the new framework study linkage between value creation cycle and organizational performance. Organizational performance divides into two categories including financial and non-financial performance. Financial performance deals with financial indicators such as return on investment (ROI), return on equity (ROE), return on assets (ROA), and operating income (OI). And also non-financial performance focuses on related indicators such as Access to capital, business value, business savings and social value.

According to the past researches and gap in literature review, the new framework suggests the organizational dimensions as control variable. Although, there are two main types of organizational dimensions including structural and contextual dimensions, this paper uses from more important them such as culture, technology, centralization, and training (see variables table).

\section{Conclusion}

Corporate social responsibility is a new tool for organizations and their managers' account for society. The fundamental concept of this tool is the mutual dependence between corporate and society. The mutual dependence, in turn, can create value for both corporate and society. Some factors such as increasing of environmental awareness, increasing scarcity of tangible and intangible resources, and transparency of operations and functions have impact on it time to time.

As well as corporate social responsibility uses from four main responsibility such as economic, legal, ethical, and philanthropy create various opportunities for top management so that reducing cost and enhancing power of organizations' competitive. In addition to, organizations shift towards excellence corporate citizenship whereby increase customer, employee and stakeholder loyalty. 
Many researches explored that corporate social responsibility impact on different aspects of organization such as financial performance and environmental performance, and also confirmed the relationship between CSR and aspects of society. This paper suggests that can measure and examine the relationship between CSR and corporation performance as integration research.

Corporate social responsibility through design the elements of organization such as strategy, resource and process, business propositions, and stakeholder interactions create value for corporations and society and also can represent excellence image in both internal and external environment. Each of these elements is measurable.

This paper suggests that after collecting data and reliability of the sample that are always problematic in the CSRs' researches and use from common software such as SPSS and MINITAB can measure and determine the impact of main elements with specific percentage on organization performance. This process and enough time are as limitation in this paper. For future need some study about the role of organization elements like strategy, tangible and intangible resource, and so on in the creation value cycle or process through corporate social responsibility and also studies about measuring methods of CSR. As well as compare with each other.

To sum up, corporate social responsibility establish a new atmosphere for corporations whereby they create wealth, maximizing earning per share, and strong competitive as well as make law-abiding company citizen and present goods and services with minimum legal requirements. Finally, make business with right; just, and fair and likewise improve quality of live for community. CSR is necessary for recent era.

\section{References}

Abbott, W., and R. Monsen. (1979). On the measurement of corporate social responsibility: self-reported disclosures as a method of measuring corporate social involvement. Academy of Management Journal, 22(3): 501-515. doi:10.2307/255740, http://dx.doi.org/10.2307/255740

Aguilera, R., \& D. Rupp, et al. (2004). Putting the S back in corporate social responsibility: A multi-level theory of social change in organizations. Academy of Management Review.

Aras, G., \& A. Aybars, et al. (2010). Managing corporate performance: Investigating the relationship between corporate social responsibility and financial performance in emerging markets. International Journal of Productivity and Performance Management, 59(3): 229-254. doi:10.1108/17410401011023573, http://dx.doi.org/10.1108/17410401011023573

Aupperle, K., \& A. Carroll, et al. (1985). An empirical examination of the relationship between corporate social responsibility and profitability. Academy of Management Journal, 28(2): 446-463. doi:10.2307/256210, http://dx.doi.org/10.2307/256210

Bansal, P., and K. Roth (2000). Why companies go green: a model of ecological responsiveness. Academy of Management Journal, 43(4): 717-736. doi:10.2307/1556363, http://dx.doi.org/10.2307/1556363

Baron, D. (2001). Private politics, corporate social responsibility, and integrated strategy. Journal of Economics \& Management Strategy, 10(1): 7-45. doi:10.1162/105864001300122548, http://dx.doi.org/10.1162/105864001300122548

Basil, D., and D. Weber. (2006). Values motivation and concern for appearances: the effect of personality traits on responses to corporate social responsibility. International Journal of Nonprofit and Voluntary Sector Marketing, 11(1): 61-72. doi:10.1002/nvsm.38, http://dx.doi.org/10.1002/nvsm.38

Bowen, H. (1953). Social responsibilities of the businessman. Harper.

Carroll, A. (1979). A three-dimensional conceptual model of corporate performance. Academy of Management Review, 497-505.

Carroll, A. (1999). Corporate social responsibility. Business \& Society, 38(3): 268. doi:10.1177/000765039903800303, http://dx.doi.org/10.1177/000765039903800303

Chen, K., and R. Metcalf. (1980). The relationship between pollution control record and financial indicators revisited. Accounting Review, 55(1): 168-177.

Cochran, P., and R. Wood. (1984). Corporate social responsibility and financial performance. Academy of Management Journal, 27(1): 42-56. doi:10.2307/255956, http://dx.doi.org/10.2307/255956

Daft, R., and A. Lewin. (1993). Where are the theories for the" new" organizational forms? An editorial essay. Organization Science, 1.

Dentchev, N. (2004). Corporate social performance as a business strategy. Journal of Business Ethics, 55(4): 395-410. doi:10.1007/s10551-004-1348-5, http://dx.doi.org/10.1007/s10551-004-1348-5

Fitch, H. (1976). Achieving corporate social responsibility. Academy of Management Review, 1(1): 38-46.

Galbreath, J. (2006). Corporate social responsibility strategy: strategic options, global considerations. Corporate Governance, 6(2): 175-187. doi:10.1108/14720700610655178, http://dx.doi.org/10.1108/14720700610655178

Hackston, D., and M. Milne. (1996). Some determinants of social and environmental disclosures in New Zealand companies. Accounting, Auditing \& Accountability Journal, 9(1): 77-108. doi:10.1108/09513579610109987, 
http://dx.doi.org/10.1108/09513579610109987

Krippendorff, K. (2004). Content analysis: An introduction to its methodology. Sage Publications, Inc.

Luo, X., and C. Bhattacharya. (2006). Corporate social responsibility, customer satisfaction, and market value. Journal of Marketing, 70(4): 1-18. doi:10.1509/jmkg.70.4.1, http://dx.doi.org/10.1509/jmkg.70.4.1

Maignan, I., \& O. Ferrell, et al. (1999). Corporate citizenship: cultural antecedents and business benefits. Journal of the Academy of Marketing Science, 27(4): 455. doi:10.1177/0092070399274005, http://dx.doi.org/10.1177/0092070399274005

Maignan, I., and D. Ralston. (2002). Corporate social responsibility in Europe and the US: Insights from businesses self-presentations. Journal of International Business Studies, 33(3): 497-514. doi:10.1057/palgrave.jibs.8491028, http://dx.doi.org/10.1057/palgrave.jibs.8491028

Margolis, J., and J. Walsh. (2003). Misery loves companies: Rethinking social initiatives by business. Administrative Science Quarterly, 48(2): 268-305. doi:10.2307/3556659, http://dx.doi.org/10.2307/3556659

Márquez, A., and C. Fombrun. (2005). Measuring corporate social responsibility. Corporate Reputation Review, 7(4): 304-308.

Maskrey, A. (1989). Disaster mitigation: a community based approach. Development Guidelines (United Kingdom).

McGuire, J., \& A. Sundgren, et al. (1988). Corporate social responsibility and firm financial performance. Academy of Management Journal, 854-872. doi:10.2307/256342, http://dx.doi.org/10.2307/256342

McWilliams, A., \& D. Siegel, et al. (2006). Corporate Social Responsibility: Strategic Implications. Journal of management studies, 43(1): 1-18. doi:10.1111/j.1467-6486.2006.00580.x, http://dx.doi.org/10.1111/j.1467-6486.2006.00580.x

McWilliams, A., and D. Siegel. (2000). Corporate social responsibility and financial performance: correlation or $\begin{array}{lllll}\text { misspecification? } & \text { Strategic } & \text { Management } & \text { Journal, } & \text { 21(5): }\end{array}$ doi:10.1002/(SICI)1097-0266(200005)21:5<603::AID-SMJ101>3.0.CO;2-3,

http://dx.doi.org/10.1002/(SICI)1097-0266(200005)21:5<603::AID-SMJ101>3.0.CO;2-3

Meehan, J., \& K. Meehan, et al. (2006). Corporate social responsibility: the 3C-SR model. International Journal of Social Economics, 33(5/6): 386-398. doi:10.1108/03068290610660661, http://dx.doi.org/10.1108/03068290610660661

Montabon, F., \& R. Sroufe, et al. (2007). An examination of corporate reporting, environmental management practices and firm performance. Journal of Operations Management, 25(5): 998-1014. doi:10.1016/j.jom.2006.10.003, http://dx.doi.org/10.1016/j.jom.2006.10.003

Nohria, N., and S. Ghoshal (1994). Differentiated fit and shared values: Alternatives for managing headquarters subsidiary relations. Strategic Management Journal, 15(6): 491-502. doi:10.1002/smj.4250150606, http://dx.doi.org/10.1002/smj.4250150606

Normann, R., and R. Ramirez. (1993). From value chain to value constellation: designing interactive strategy. Harvard business review, 71: 65-65.

Orlitzky, M., \& F. Schmidt, et al. (2003). Corporate social and financial performance: A meta-analysis. Studies, 24(3): 403-441.

Schwartz, M., and A. Carroll. (2003). Corporate social responsibility: A three-domain approach. Business Ethics Quarterly, 13(4): 503-530.

Shropshire, C., and A. Hillman. (2007). A longitudinal study of significant change in stakeholder management. Business \& Society, 46(1): 63. doi:10.1177/0007650306295753, http://dx.doi.org/10.1177/0007650306295753

Stanwick, P., and S. Stanwick. (1998). The relationship between corporate social performance, and organizational size, financial performance, and environmental performance: An empirical examination. Journal of Business Ethics, 17(2): 195-204. doi:10.1023/A:1005784421547, http://dx.doi.org/10.1023/A:1005784421547

Turban, D., and W. Daniel. (1996). Greening.(1996). Corporate social performance and organizational attractiveness to prospective employees. Academy of Management Journal, 40(3): 658-672. doi:10.2307/257057, http://dx.doi.org/10.2307/257057

Udayasankar, K. (2008). Corporate social responsibility and firm size. Journal of Business Ethics, 83(2): 167-175. doi:10.1007/s10551-007-9609-8, http://dx.doi.org/10.1007/s10551-007-9609-8

Ullmann, A. (1985). Data in search of a theory: A critical examination of the relationships among social performance, social disclosure, and economic performance of US firms. Academy of Management Review, 10(3): 540-557.

Waddock, S., and S. Graves. (1997). The corporate social performance-financial performance link. Strategic Management 
doi:10.1002/(SICI)1097-0266(199704)18:4<303::AID-SMJ869>3.0.CO;2-G,

http://dx.doi.org/10.1002/(SICI)1097-0266(199704)18:4<303::AID-SMJ869>3.0.CO;2-G

Weber, R. (1990). Basic content analysis (Quantitative Applications in the Social Sciences No. 49), Newbury Park, CA: Sage.

Wood, D. (1991). Corporate social performance revisited. Academy of Management Review, 16(4): 691-718.

Table 1. Variables table

\begin{tabular}{|c|c|c|c|c|c|c|c|}
\hline \multirow[t]{2}{*}{ NO } & \multicolumn{4}{|l|}{ IV } & \multirow{2}{*}{$\begin{array}{l}\mathrm{CV} \\
\text { Organizational } \\
\text { Dimensions } \\
\end{array}$} & \multicolumn{2}{|l|}{ DV } \\
\hline & Economic & Legal & Ethical & Philanthropic & & Financial & Non-financial \\
\hline 1 & $\begin{array}{l}\text { Personal } \\
\text { Saving rate }\end{array}$ & Anti-trust & $\begin{array}{l}\text { Codes of } \\
\text { conduct }\end{array}$ & $\begin{array}{l}\text { Donor } \\
\text { attrition }\end{array}$ & Culture & ROI & $\begin{array}{ll}\begin{array}{l}\text { Access } \\
\text { capital }\end{array} & \text { to } \\
\end{array}$ \\
\hline 2 & $\begin{array}{l}\text { Business } \\
\text { saving rate }\end{array}$ & $\begin{array}{l}\text { Labor } \\
\text { training } \\
\text { laws } \\
\end{array}$ & corruption & $\begin{array}{l}\text { Donor } \\
\text { acquisition }\end{array}$ & Technology & ROE & $\begin{array}{l}\text { Business } \\
\text { value }\end{array}$ \\
\hline 3 & Inflation rate & $\begin{array}{l}\text { Taxation } \\
\text { law }\end{array}$ & $\begin{array}{l}\text { Money } \\
\text { laundering }\end{array}$ & $\begin{array}{l}\text { Gift } \\
\text { processing } \\
\text { time }\end{array}$ & Centralization & ROA & $\begin{array}{l}\text { Business } \\
\text { savings }\end{array}$ \\
\hline 4 & $\begin{array}{l}\text { Manufacturing } \\
\text { lead time }\end{array}$ & $\begin{array}{l}\text { Human } \\
\text { right }\end{array}$ & & $\begin{array}{l}\text { Stewardship } \\
\text { calls }\end{array}$ & Training & OI & Social value \\
\hline
\end{tabular}

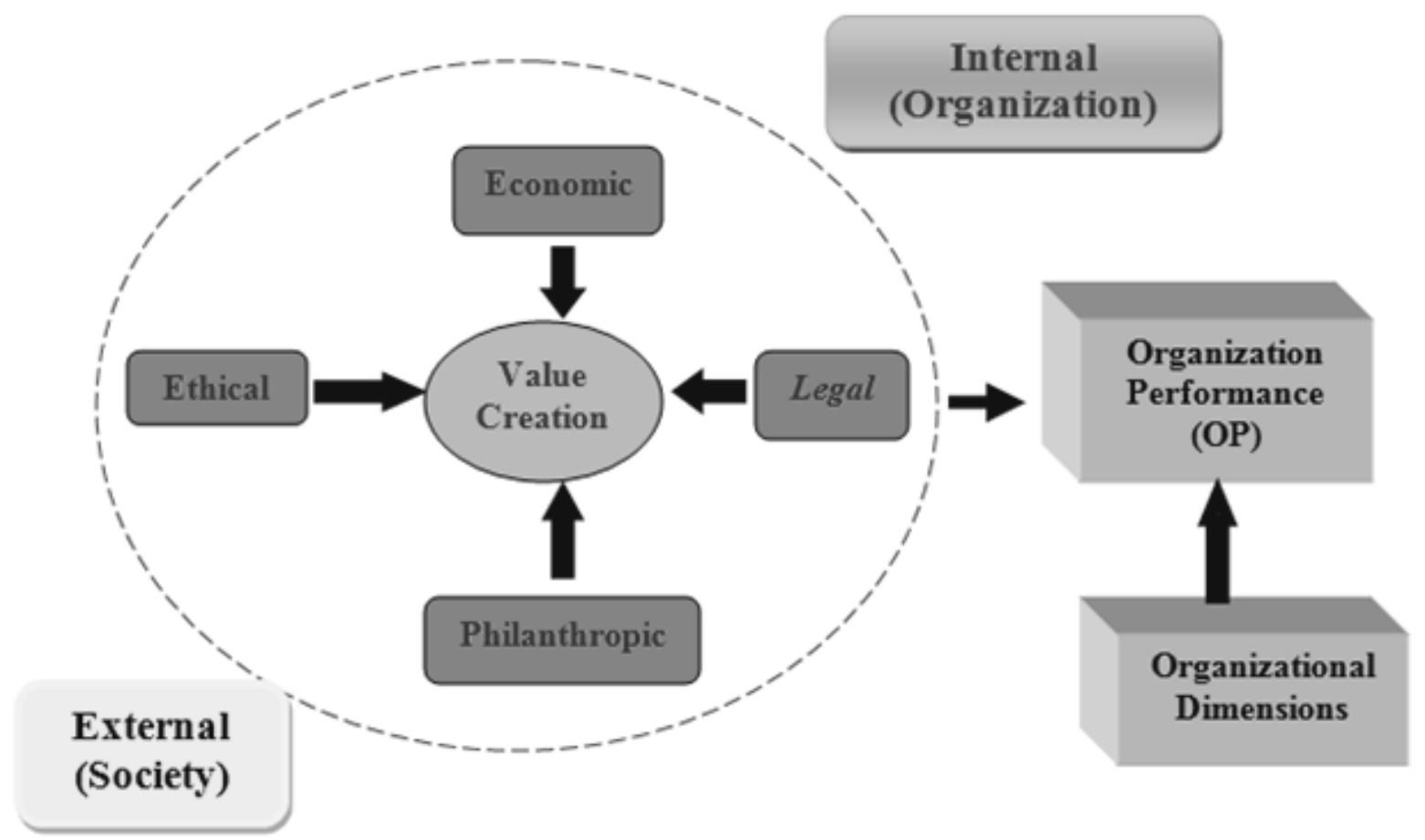

Figure 1. Conceptual framework 